OPEN ACCESS

Edited by:

Dan Kneeshaw,

Université du Québec à

Montréal, Canada

Reviewed by:

Mike Cruickshank,

Canadian Wood Fibre Centre, Canada

Marcus Warwell,

United States Forest Service (USDA),

United States

${ }^{*}$ Correspondence:

Ryan Stevens

rpsteven@lakeheadu.ca

Specialty section: This article was submitted to

Forest Disturbance,

a section of the journal Frontiers in Forests and Global

Change

Received: 24 August 2020 Accepted: 02 November 2020 Published: 23 November 2020

Citation:

Stevens $R$, Reyes $G$ and Kanavillil N (2020) Examining the Impact of Winter and Spring Soil Temperatures on the Growth of Hypholoma fasciculare, a

Potential Biocontrol Agent Against Armillaria ostoyae, in Pine Plantations. Front. For. Glob. Change 3:598527. doi: 10.3389/ffgc.2020.598527

\section{Examining the Impact of Winter and Spring Soil Temperatures on the Growth of Hypholoma fasciculare, a Potential Biocontrol Agent Against Armillaria ostoyae, in Pine Plantations}

\author{
Ryan Stevens*, Gerardo Reyes and Nandakumar Kanavillil \\ Department of Biology and Sustainability Sciences, Lakehead University, Orillia, ON, Canada
}

Hypholoma fasciculare is regarded as a potentially effective biocontrol agent against Armillaria root disease. However, trials examining its effectiveness are currently limited to controlled lab conditions and field studies conducted mostly during the summer season. We examined the ability of $H$. fasciculare to survive and grow underground during the winter and spring seasons to offer insight on its ability to provide year-round protection. Pine blocks inoculated with $\mathrm{H}$. fasciculare were buried in three thinned pine plantations at 30 and $100 \mathrm{~cm}$ depths from February 1, 2018 to May 13, 2018 (101 days) to examine how winter and spring soil temperatures at two different soil depths impacted growth. A significant interactive effect of soil depth and month on soil temperature $\left(F_{3,40}=15.94, p<0.001\right)$ was observed. Mean growth rates did not vary significantly between the two soil depths $\left(F_{1,23}=0.91, p=0.393\right)$ as growth rates were $0.25 \pm 0.11$ and $0.31 \pm 0.10 \mathrm{~mm} /$ day at 30 and $100 \mathrm{~cm}$ depths, respectively. Our study supports developing $\mathrm{H}$. fasciculare as a biocontrol agent against Armillaria root disease given its ability to grow underground during the winter and early spring seasons, a period during which Armillaria has a reduced growing capacity.

Keywords: Hypholoma, winter, soil, Armillaria, biocontrol

\section{INTRODUCTION}

Hypholoma fasciculare is a promising biocontrol option against Armillaria root disease within north temperate and boreal forests across North America. Armillaria root disease is caused by an assortment of Armillaria species and resultantly, impacts a broad range of host species (Raabe, 1962; Baumgartner et al., 2011). Our focus here is on Armillaria ostoyae, a highly virulent pathogenic species that causes extensive mortality in pine plantations (Filip et al., 2010; McLaughlin et al., 2011; Lockman and Kearns, 2016). Armillaria ostoyae can rapidly spread within conifer plantations by means of root-to-root contact and via soil rhizomorph production (Toussoun et al., 1970; Myren et al., 1994). Spread is particularly troublesome after thinning interventions due to the sudden increase in inoculum potential. 
An acceptable silvicultural treatment to control the spread of Armillaria root disease has remained elusive given its aggressiveness, multiple modes of dispersal, and ability to persist on infected stumps for more than 35 years (Redfern and Filip, 1991; Goheen and Otrosina, 1998). Treatment costs, ecological impacts, and safety are also key concerns, making use of certain mechanical techniques such as stump removal or soil fumigation problematic (Baumgartner et al., 2011; Shaw et al., 2012; Chen et al., 2019). Given these concerns, alternative management approaches such as use of naturally occurring antagonistic fungi as biocontrol agents is drawing more interest.

Hypholoma fasciculare has shown promise toward controlling Armillaria root disease spread. Keča (2009) found that invitro growth of $H$. fasciculare is stimulated by the presence of Armillaria species, ultimately inhibiting Armillaria colony growth and rhizomorph production. In other lab trials, $H$. fasciculare outcompeted A. ostoyae on root segments buried in sand maintained at $20^{\circ} \mathrm{C}$ (Chapman and Xiao, 2000). Field trials are limited, although Chapman and Xiao (2000) and Chapman et al. (2004) inoculated stumps in recently cut conifer stands with $H$. fasciculare, which prevented Armillaria growth on root segments where both $A$. ostoyae and $H$. fasciculare were inoculated. Root segments that had $50-80 \%$ coverage from $H$. fasciculare were found to have $\sim 10 \%$ of the cambium occupied by A. ostoyae.

There are many potential climatic and environmental factors that can limit the efficacy of $H$. fasciculare as a biocontrol agent in field conditions that require investigation. Soil temperature, for example, is critical for fungi establishment, growth, and survival (Rishbeth, 1978; Wells and Boddy, 1995; Pietikäinen et al., 2005; Voríšková et al., 2014). Growth rates of fungi decline as soil temperatures decrease (Rishbeth, 1978; Pearce and Malajczuk, 1990; Wells and Boddy, 1995; Pietikäinen et al., 2005), and threshold temperatures wherein activity slows or stops differ among species. Hypholoma fasciculare is still able to decay wood at $5^{\circ} \mathrm{C}$ (Wells and Boddy, 1995) while rhizomorph production stalls as soil temperatures approach $10^{\circ} \mathrm{C}$ or lower for many Armillaria species (Rishbeth, 1978; Pearce and Malajczuk, 1990). Fungi growth may also be impacted by soil depth given the differences in seasonal and diurnal fluctuations in temperature and oxygen concentration at different depths within the soil solum (Baker, 1971; Rishbeth, 1978; Carreiro and Koske, 1992). Armillaria luteobubalina, for example, produces significantly more rhizomorphs at $12 \mathrm{~cm}$ depth compared to $28 \mathrm{~cm}$ (Pearce and Malajczuk, 1990). Redfern (1973) reported A. mellea rhizomorphs were concentrated between 2.5 and $20 \mathrm{~cm}$ soil depths and rarely found below $30 \mathrm{~cm}$. Note however, that Thompson and Boddy (1983) observed Armillaria species occupying deeper sections of tree roots while cord-forming fungi were concentrated around the root collar, suggesting that interspecific interactions may influence establishment patterns along the soil profile.

Few investigators have examined fungi activity in soil during the winter and early spring months in north temperate forests (e.g., Coutts and Nicoll, 1990; Kuhnert et al., 2012). In particular, the lack of knowledge on $H$. fasciculare activity in pine plantation soils during this dormant period for most north temperate plants is an obstacle for its development as a biocontrol agent against Armillaria root disease. The purpose of this study was to determine if $H$. fasciculare continues to grow on pine blocks buried at different depths during the winter and spring seasons, and thus, provide evidence that it can offer year-round protection against $A$. ostoyae infection of red pine plantations.

\section{METHODS}

\section{Study Area}

The study was conducted within red pine (Pinus resinosa) plantations located in Simcoe County, Ontario, Canada. Pine plantations make up $\sim 50 \%$ of all production forest across the County (County of Simcoe, 2011). Three, even-aged mature plantations were used for this study (Figure 1). Plantations were $\sim 60$ years of age and were pre-commercially thinned from the age of 30-35 years with $\sim 9$ years between thinning interventions. Thus, each plantation has undergone multiple pre-commercial thinning interventions, of which the three plantations were last cut in 2009, 2013, and 2015, respectively. Basal area at the time of sampling was $21 \mathrm{~m}^{2} /$ ha for plantation $1\left(44.628^{\circ} \mathrm{N}\right.$, $\left.79.747^{\circ} \mathrm{W}\right), 30 \mathrm{~m}^{2} /$ ha for plantation $2\left(44.570^{\circ} \mathrm{N}, 79.654^{\circ} \mathrm{W}\right)$, and $26 \mathrm{~m}^{2} /$ ha for plantation $3\left(44.539^{\circ} \mathrm{N}, 79.631^{\circ} \mathrm{W}\right)$. Field observations confirmed the presence of Armillaria within the plantations thinned in 2009 and 2013.

Armillaria root disease is an important natural disturbance that impacts the majority of pine plantations across Simcoe County to some degree, forcing an early removal of red pine trees from many plantations to salvage the timber (McLaughlin, 2001; County of Simcoe, 2011). Simcoe County is in the Mixedwood Plains Ecozone of Ontario, Canada (Lee et al., 1998). Climate in the region is cool temperate. Mean annual temperature is $6.9 \pm 1.4^{\circ} \mathrm{C}$ while mean January and July temperatures are $-7.7 \pm 3.4$ and $20.8 \pm 1.3^{\circ} \mathrm{C}$, respectively (Government of Canada, 2019). Mean annual precipitation is $932.9 \mathrm{~mm}$, with $\sim 76.1 \%$ falling as rain. General topography is flat to rolling. Soils originate from glacial tils (Hoffman et al., 1962) and are characterized as Vasl-s and Tisl sandy loams with good drainage (Canada Department of Agriculture, 1959). The organic layer within the plantations was $5.8 \pm 0.8 \mathrm{~cm}$, A horizon depth was $17.8 \pm 4.8 \mathrm{~cm}$, B horizon depth was $46 \pm 18.5 \mathrm{~cm}$, and $\mathrm{C}$ horizon depth could not be fully measured but extended beyond the $\mathrm{B}$ horizon depths.

\section{Monitoring $\boldsymbol{H}$. fasciculare Activity According to Soil Temperature and Depth}

Twenty-four pine wood blocks $(2.5 \times 2.5 \times 20 \mathrm{~cm})$ were inoculated with $H$. fasciculare strain Pinnel B. This strain was chosen based on in-vitro competition trials with Armillaria ostoyae by Stevens (2019). An inoculum plug of $H$. fasciculare $(10 \mathrm{~mm})$ was obtained from a freshly cultured medium (2\% Malt Agar) and placed on one $2.5 \times 2.5 \mathrm{~cm}$ end of each wooden block ( 1 plug per block). The blocks were placed in a growth chamber and incubated in the dark at $24^{\circ} \mathrm{C}$. The blocks were incubated for 9.5 weeks (67 days) to ensure sufficient mycelium growth for the field experiment (i.e., $\sim 25 \%$ of each block was colonized by $H$. fasciculare). 


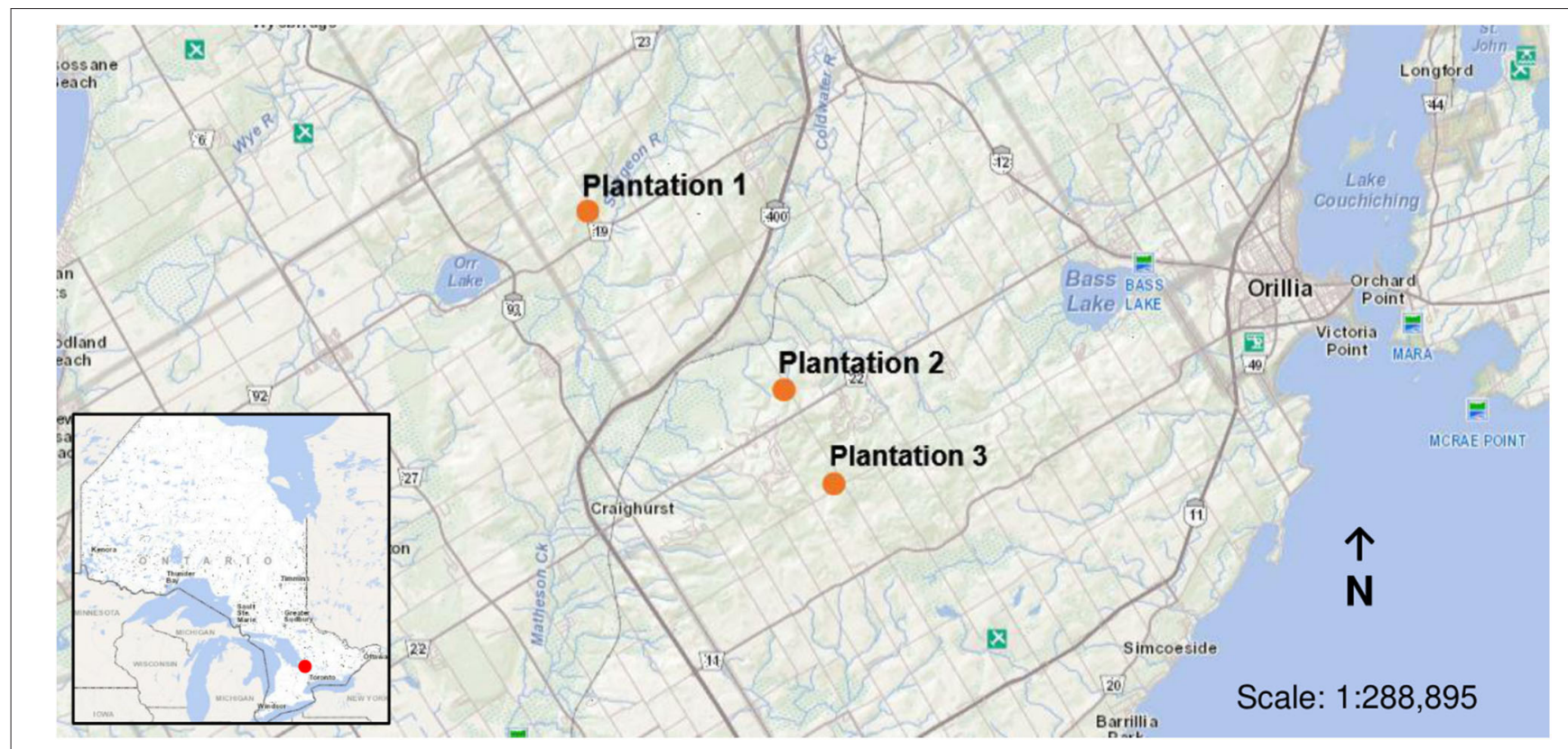

FIGURE 1 | Location of sample sites for the deployment of soil temperature data loggers and inoculated wooden blocks (indicated in orange) within red pine (Pinus resinosa) plantations located in Simcoe County, ON.

Four colonized blocks were buried at 30 and $100 \mathrm{~cm}$ depths each in the three plantations from February 1, 2018 (mid-winter) to May 13, 2018 (mid-spring). Blocks were placed $\sim 6$ inches apart at each depth. Soil horizons were not maintained during the burial procedure of the blocks. Plot locations were randomly chosen within each of the plantations and were separated by $\sim 2 \mathrm{~m}$. These two depths were selected for deployment because red pine generally produce shallow horizontal roots for nutrient uptake (20 $\pm 10 \mathrm{~cm}$ deep) and deep vertical roots for anchoring $(100 \pm 50 \mathrm{~cm})$ (Fayle, 1975). Hypholoma fasciculare growth along each $20 \mathrm{~cm}$ block face (four sides lengthwise) was measured and averaged before being buried horizontally underground. The growth of mycelium from the block edge to the growth front was initially measured before block placement and was immediately re-measured upon retrieval to determine the growth rate and overall growth achieved. Please note that positive identification of Hypholoma was made using visual and scent cues only. Cultures were not taken from the blocks after retrieval leaving the potential that some of the growth was another fungus species.

Concurrently within each plantation, two temperature probes (OMEGA ${ }^{\circledR}$ OM-SP-MICROTEMP) were placed in the soil near the colonized blocks, one at $30 \mathrm{~cm}$ and one at $100 \mathrm{~cm}$ depths. The data loggers collected soil temperature readings every $12 \mathrm{~h}$ at 02:00 and 14:00 from February 1, 2018 to May 13, 2018. Thus, 203 measurements were obtained from each soil data logger over the 101 day study period. Soil temperatures at the time of block burial (February 1, 2018) were $1 \pm 0.78 \mathrm{SE}$ and $2.6 \pm 0.48 \mathrm{SE}{ }^{\circ} \mathrm{C}$ at 30 and $100 \mathrm{~cm}$ soil depths, respectively, and $7.5 \pm 1.56 \mathrm{SE}$ and $4.9 \pm 2.19 \mathrm{SE}^{\circ} \mathrm{C}$ at 30 and $100 \mathrm{~cm}$ soil depth, respectively, at the time of block removal (May 13, 2018).

\section{Statistical Analyses}

Soil temperatures were averaged for each day as an initial analysis concluded that there were no significant differences in temperature readings between $02: 00$ and 14:00 $\mathrm{h}$ on a day at a site $(t=-0.225$, df $=2278, p=0.822)$. We compared mean monthly soil temperatures between sites at each soil depth using repeated measures ANOVA $(\alpha=0.05)$. Impact of soil depth $(30$ and $100 \mathrm{~cm}$ ) and site influence on $H$. fasciculare growth was examined using a nested ANOVA $(\alpha=0.05)$. Burial depths within each site were nested as a random factor to account for the variation in Hypholoma growth between each site. A Bartlett's Test for Homogeneity of Variances indicated that the data were homogeneic while Anderson Darling normality tests indicated that the data were normally distributed. All statistical tests were run using $\mathrm{R}$ Studio version 1.3.1093 ( $\mathrm{R}$ version 3.5.3). $\mathrm{R}$ packages used include carData (v 3.0-4), ggplot2 (v 3.3.2), lattice (v 0.20-41), lmerTest (v 3.1-2), and nortest (v 1.0-4).

\section{RESULTS}

\section{Soil Temperature and Depth}

A significant temperature difference between month $\left(F_{3,602}=449.955, p<0.001\right)$ and soil depth $\left(F_{1,602}=30.907\right.$, $p<0.001)$ was observed. A significant interactive effect of soil depth and month on soil temperature $\left(F_{3,602}=169.653\right.$, $p<0.001)$ was observed. Soil temperature gradually declined over the course of the winter season at both depths, and then increased more rapidly by mid-April at $30 \mathrm{~cm}$ than at $100 \mathrm{~cm}$ (Figure 2). At $30 \mathrm{~cm}$, soil temperature gradually declined until April 19, 2018, reaching a low of $0.6 \pm 0.37 \mathrm{SE}{ }^{\circ} \mathrm{C}$. The nadir for soil temperature at $100 \mathrm{~cm}$ depth occurred on April 26, 


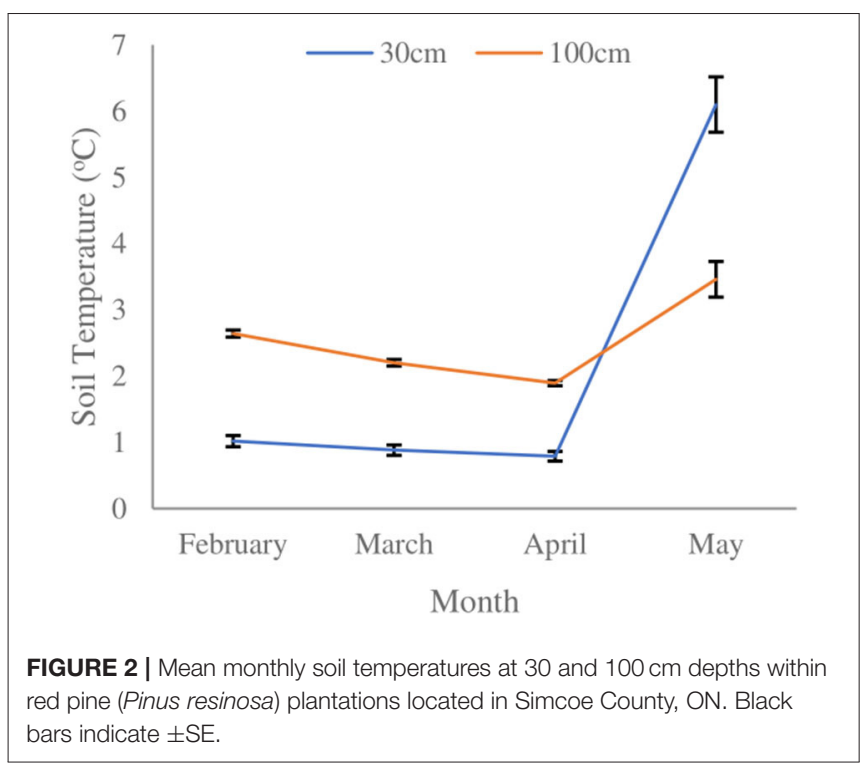

2018, reaching a low of $1.7 \pm 0.20 \mathrm{SE}^{\circ} \mathrm{C}$. After April 26, 2018, a rapid increase in soil temperature was observed at $30 \mathrm{~cm}$ depth, which continued until the day the blocks were excavated. Soil temperature increase during spring at $100 \mathrm{~cm}$ depth was more gradual. Soil temperature at $30 \mathrm{~cm}$ depth was $\sim 1.6^{\circ} \mathrm{C}$ colder than at $100 \mathrm{~cm}$ depth until early spring when temperatures rose sharply, eventually exceeding that observed at $100 \mathrm{~cm}$ depth. At the time of block extraction soil temperature was $\sim 2.6^{\circ} \mathrm{C}$ warmer at the shallower depth.

\section{H. fasciculare Growth in Response to Burial Depth}

No significant difference in $H$. fasciculare growth was observed between 30 and $100 \mathrm{~cm}$ burial depths $\left(F_{1,23}=0.91, p=0.393\right)$ or between depths within sites $\left(F_{4,23}=2.05, p=0.129\right)$ (Figure 3). Inoculated blocks from plantation 1 were very moist at both depths, which was indicative of the surrounding soil conditions. The hyphae were clearly visible on the wood blocks extracted from these sites (Figure 4) and had a very distinctive smell that indicates its vitality as also noted by Chapman and Xiao (2000). On drier blocks the growth appeared as dark coloration on the wood. Hypholoma fasciculare at $30 \mathrm{~cm}$ depth grew an average of $0.25 \pm 0.03 \mathrm{SE} \mathrm{mm} /$ day whereas the $H$. fasciculare at $100 \mathrm{~cm}$ depth grew on average $0.31 \pm 0.03 \mathrm{SE} \mathrm{mm}$ /day.

\section{DISCUSSION}

\section{Soil Temperature and Depth}

Soil fungi activity is impacted by variation in soil temperatures (Biederbeck and Campbell, 1973). Most research examining temperature effects on soil fungi activity have focused on growth during the summer growing season and/or maintained constant temperature regimes in controlled laboratory studies (Dowson et al., 1989; Pearce and Malajczuk, 1990; Chapman and Xiao, 2000). However, wide diurnal and seasonal fluctuations

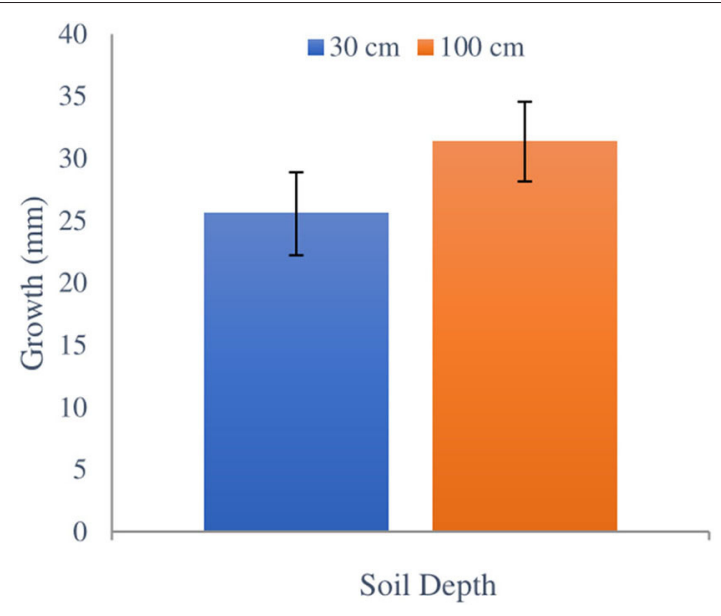

FIGURE 3 | Comparing total growth of $H$. fasciculare between 30 and $100 \mathrm{~cm}$ soil depths during winter and early spring seasons from February 1 to May 13, 2018. Black bars indicate \pm SE.

in soil temperature can occur in nature (Biederbeck and Campbell, 1973). Thus, published results may not accurately reflect fungi activity in sub-optimal conditions that occur during the non-growing season within north temperate pine plantations.

Our study has shown that soil temperatures within plantation forests exhibit seasonal changes whose rate and amplitude are dependent on soil depth. As anticipated, temperatures at the shallower soil depth fluctuated more rapidly and with greater amplitude than in deeper soil given the greater susceptibility to changes in ambient air temperature. Deeper soils have a higher insulation value, leading to warmer, more stable temperatures over winter, and a slower rise in temperatures at the onset of the spring season (Yin and Arp, 1993; Decker et al., 2003). In our sites, soil temperatures were $1-2^{\circ} \mathrm{C}$ higher at the deeper depth during winter until the middle of spring, when shallower soils warmed more quickly and surpassed maximum temperatures observed at the deeper depth. The more rapid increase in soil temperature at the shallow depth could be related to the absence of snow cover during the month of May, allowing for greater absorption of radiant heat.

\section{H. fasciculare Growth in Response to Burial Depth}

The soil temperature lows reached during the winter and spring seasons at both shallow and deep soil depths did not prevent $H$. fasciculare growth. Mean growth rates of $H$. fasciculare observed in our study $(0.25 \pm 0.11 \mathrm{SE}$ and $0.31 \pm 0.10 \mathrm{SE} \mathrm{mm} /$ day at 30 and $100 \mathrm{~cm}$ depths, respectively) exceeded that observed by Dowson et al. (1989) at $5^{\circ} \mathrm{C}$ in-vitro on $2 \%$ malt extract agar $(0.2 \mathrm{~mm} /$ day $)$. Differences in growth rates may be related to the strain of $H$. fasciculare chosen in our respective studies as variation in growth rates among fungi strains of the same species can occur (Stevens, 2019). The strain used by Dowson et al. (1989) was not indicated in their study. The ability of 


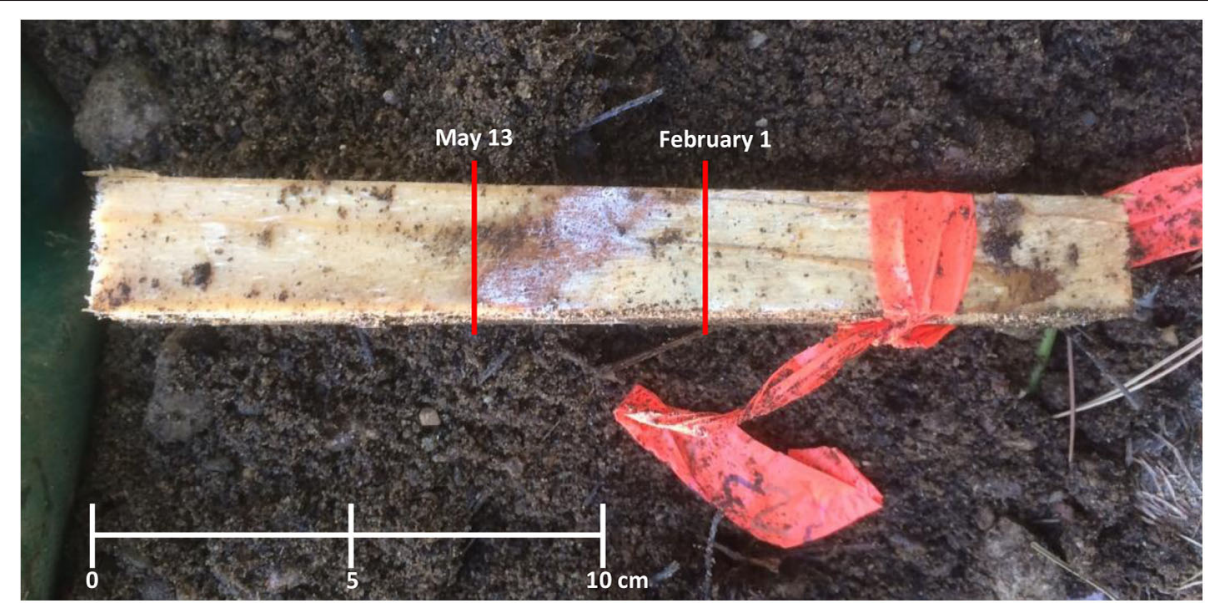

FIGURE 4 | Hypholoma fasciculare growth during winter and spring on pine block buried at $30 \mathrm{~cm}$ depth. The white hyphae indicate growth of $H$. fasciculare. The area marked in red lines indicate the growth of $H$. fasciculare from February 1 to May 13, 2020.

$H$. fasciculare to grow during the winter and spring seasons takes advantage of a period when Armillaria is believed to be dormant due to low temperatures (Rishbeth, 1968, 1978). Resource capture during this period would also reduce the inoculum potential of Armillaria species when active during the growing season. Moreover, $H$. fasciculare has been shown to overgrow Armillaria species in lab-based interaction trials and may also parasitize Armillaria as lysis was evident (Thompson and Boddy, 1983; Chapman and Xiao, 2000; Stevens, 2019). Thus, inhibition of Armillaria spread through pre-emptive resource capture by $H$. fasciculare during winter may aid in reducing the inoculum potential for Armillaria root rot throughout plantations.

No differences in growth rate in relation to soil depth were evident, indicating that the significant differences in temperature were not perceived by $H$. fasciculare. The activity observed at deeper depths contrasts Thompson and Boddy (1983), who suggest that $H$. fasciculare may not persist in deeper root systems. Documenting $H$. fasciculare activity at greater depths under natural climate conditions during the winter and spring seasons indicates that $H$. fasciculare may at least colonize unoccupied roots and stump tissue (and thus perhaps function continuously throughout the year as a biocontrol agent), at least to depths of $1 \mathrm{~m}$ in the soil solum. This is important as Armillaria species have been documented as being active within this range of soil depths (Redfern, 1973; Thompson and Boddy, 1983; Pearce and Malajczuk, 1990).

Note that near surface soil temperatures $(\leq 10 \mathrm{~cm}$ depth) were not monitored. Potentially colder soil temperatures and frozen conditions could have impacted fungi activity near the surface (Robinson, 2001; Decker et al., 2003; Ma et al., 2011). Further study is needed to determine if $H$. fasciculare is tolerant of sub-zero temperatures in addition to the mechanisms it would use to maintain cell integrity. The rapid vs. slow change in temperature during spring at the different depths did not appear to impact $H$. fasciculare survival and/or growth rates. This agrees with Burgess and Griffin (1968) who found that temperature fluctuation does not affect fungal growth rate. Moreover, all $H$. fasciculare colonies on all blocks used in our study exhibited growth. However, although fungi growth rates were similar among sites, qualitative differences in level of decay among inoculated pine blocks were apparent. The pine blocks excavated from a wetter site location (plantation 1) were very dark, moist, and $H$. fasciculare hyphae were plainly visible at both depths. Blocks from drier site locations (plantation 2 and 3) were lighter in color, relatively dry, and the hyphae were less discernable. The dark and moist wood blocks had a distinct odor where the $H$. fasciculare growth established, similar to when $H$. fasciculare is found on decaying roots, indicating that the Hypholoma was active and healthy (Chapman and Xiao, 2000). This suggests that the ability of $H$. fasciculare to decay wood was greater in moist soil conditions, similar to observations by Dowson et al. (1989) and Carreiro and Koske (1992), but that growth in dry conditions may present survivability issues when Armillaria is present given its growth capability in dry soils (McLaughlin, 2001). Our methods used here did not fully account for these qualitative differences in growth and require further exploration. This is particularly important given that soil moisture content is expected to change with climate change (Kellomäki et al., 2010), which could also impact soil basidiomycete activity, function, as well as their interactions with other soil biota (A'Bear et al., 2014). Thus, $H$. fasciculare may become an important management option should conditions favor its growth given that Armillaria activity is expected to increase with climate change (Kubiak et al., 2017).

This research has potential benefits for forest managers in terms of improving productivity and achieving other long-term stand objectives across Southern Ontario and the Northern United States. A biocontrol product consisting of $H$. fasciculare could be applied to stumps after harvesting (during the summer growing season) given that it has the capacity to grow year-round within the stumps and thus provide long-term protection against Armillaria infection. Challenges still exist for using $H$. fasciculare 
strain Pinnel B as a biocontrol treatment against Armillaria root rot. The inoculum would be applied to the stumps near ground level which will expose Hypholoma to various types of weather and temperatures that may be detrimental to survival. However, Chapman and Xiao (2000) placed viable Hypholoma treatments around the trunk base during the winter months when snow was present, which suggests it can survive aboveground if proper care is taken and the inoculum is grown on the proper substrate. Further study to understand its long-term survival in other parts of northeastern North America, examine $H$. fasciculare growth rates during the summer growing season, determine whether it can naturally establish and grow on red and white pine root systems, examine the impacts of soil moisture and interspecific competition on establishment success, and determine application concentrations necessary for effective control is needed.

\section{DATA AVAILABILITY STATEMENT}

The raw data supporting the conclusions of this article will be made available by the authors, without undue reservation.

\section{AUTHOR CONTRIBUTIONS}

All three authors together designed the experiment and selected the experimental study sites. RS conducted the field work, analyzed results, and wrote the initial manuscript. NK and GR

\section{REFERENCES}

A'Bear, A. D., Jones, T. H., and Boddy, L. (2014). Potential impacts of climate change on interactions among saprotrophic cord-forming fungal mycelia and grazing soil invertebrates. Fungal Ecol. 10, 34-43. doi: 10.1016/j.funeco.2013.01.009

Baker, D. G. (1971). Snow Cover and Winter Soil Temperatures at St. Paul, Minnesota. Minneapolis, Minn.: Water Resources Research Center, University of Minnesota (1971).

Baumgartner, K., Coetzee, M., and Hoffmeister, D. (2011). Secrets of the subterranean pathosystem of Armillaria. Mol. Plant Pathol. 12, 515-534. doi: 10.1111/j.1364-3703.2010.00693.x

Biederbeck, V. O., and Campbell, C. A. (1973). Soil microbial activity is influenced by temperature trends and fluctuations. Can. J. Soil Sci. 53, 363-376. doi: $10.4141 /$ cjss73-053

Burgess, H. F., and Griffin, D. M. (1968). The influence of diurnal temperature fluctuations on the growth of fungi. New Phytol. 67, 131-137. doi: 10.1111/j.1469-8137.1968.tb05462.x

Canada Department of Agriculture (1959). Soil Survey of Simcoe County. Available online at: http://sis.agr.gc.ca/cansis/publications/surveys/on/on29/index.html (accessed July 17, 2020).

Carreiro, M. M., and Koske, R. E. (1992). Room temperature isolations can bias against selection of low temperature microfungi in temperate forest soils. Mycologia 84, 886-900. doi: 10.1080/00275514.1992.12026221

Chapman, B., and Xiao, G. (2000). Inoculation of stumps with Hypholoma fasciculare as a possible means to control Armillaria root disease. Can. J. Bot. 78, 129-134. doi: 10.1139/b99-170

Chapman, B., Xiao, G., and Myers, S. (2004). Early results from field trials using Hypholoma fasciculare to reduce Armillaria ostoyae root disease. Can. J. Bot. 82, 962-969. doi: 10.1139/b04-078

Chen, L., Bóka, B., Kedves, O., Nagy, V. D., Szucs, A., Champramary, S., et al. (2019). Towards the biological control of devastating forest pathogens from the genus Armillaria. Forests 10:1013. doi: 10.3390/f10111013 partially funded the project from their OCE (Ontario Centre of Excellence) grant, as well as reviewed and edited the manuscript. All authors approved the submitted manuscript.

\section{FUNDING}

The Ontario Centres of Excellence (Grant No. \# VIP 26689) provided support for the purchasing of OMEGA ${ }^{\circledR}$ OM-SPMICROTEMP data loggers and for other field supplies.

\section{ACKNOWLEDGMENTS}

We thank Graeme Davis (County of Simcoe) who provided technical assistance and support for the field research. Lakehead University is acknowledged for use of the facilities. We thank Lallemand Inc. for providing the fungal cultures used in this study and to Ontario Centres of Excellence (OCE) for providing financial support. We thank the two reviewers whose valuable insight and comments greatly improved this manuscript. Finally, we thank Jeremy Stevens who assisted with field work.

\section{SUPPLEMENTARY MATERIAL}

The Supplementary Material for this article can be found online at: https://www.frontiersin.org/articles/10.3389/ffgc.2020. 598527/full\#supplementary-material

County of Simcoe (2011). Simcoe County Forests 2011-2030 Forest Management Plan. Available online at: https://www.simcoe.ca/Forestry/Documents/SCF \%20final\%20report.pdf (accessed July 18, 2020).

Coutts, M. P., and Nicoll, B. C. (1990). Growth and survival of shoots, roots, and mycorrhizal mycelium in clonal Sitka spruce during the first growing season after planting. Can. J. Forest Res. 20, 861-868.

Decker, K. L. M., Wang, D., Waite, C., and Scherbatskoy, T. (2003). Snow removal and ambient air temperature effects on forest soil temperatures in Northern Vermont. Soil Sci. Soc. Am. J. 67, 1234-1242. doi: 10.2136/sssaj2003.1234

Dowson, C. G., Boddy, L., and Rayner, A. D. M. (1989). Development and extension of mycelial cords in soil at different temperatures and moisture contents. Mycol. Res. 92, 383-391. doi: 10.1016/S0953-7562(89)80181-9

Fayle, D. C. F. (1975). Extension and longitudinal growth during the development of red pine root systems. Can. J. Forest Res. 5, 109-121. doi: 10.1139/x75-016

Filip, G. M., Maffei, H. M., Chadwick, K. L., and Max, T. A. (2010). Armillaria root disease-caused tree mortality following silvicultural treatments (shelterwood or group Selection) in an Oregon mixed-conifer forest: insights from a 10-Year case study. West. J. Appl. Forest. 25, 136-143. doi: 10.1093/wjaf/25.3.136

Goheen, D. J., and Otrosina, W. J. (1998). Characteristics and Consequences of Root Diseases in Forests of Western North America, 3-8. Available online at: https:// www.treesearch.fs.fed.us/pubs/1087 (accessed July 15, 2020).

Government of Canada (2019). Canadian Climate Normals 1981-2010 Station Data. Available online at: https://climate.weather.gc.ca/climate_normals/ results_1981_2010_e.html?stnID=4408andautofwd=1 (accessed July 20, 2020).

Hoffman, D. W., Richards, N. R., and Wicklund, R. E. (1962). Soil Survey of Simcoe County. Ontario. Ottawa: Research Branch, Canada Department of Agriculture and the Ontario Agriculture College.

Keča, N. (2009). In vitro interactions between Armillaria species and potential biocontrol fungi. Glasnik Šumarskog Fakulteta. Available online at: http:// agris.fao.org/agrissearch/search.do?recordID=DJ2012056821 (accessed July 10, 2020). doi: 10.2298/GSF0900129K

Kellomäki, S., Maajärvi, M., Strandman, H., Kilpeläinen, A., and Peltola, H. (2010). Model computations on the climate change effects on snow cover, soil moisture 
and soil frost in the boreal conditions over Finland. Silva Fennica 44, 213-233. doi: 10.14214/sf.455

Kubiak, K., Zółciak, A., Damszel, A., Lech, P., and Sierota, Z. (2017). Armillaria pathogenesis under climate changes. Forests 8:100. doi: 10.3390/f8040100

Kuhnert, R., Oberkofler, I., and Peintner, U. (2012). Fungal growth and biomass development is boosted by plants in snow-covered soil. Microb. Ecol. 64, 79-90. doi: 10.1007/s00248-011-0001-y

Lee, H., Bakowsky, W., Riley, J., Bowles, J., Puddister, M., Uhlig, P., et al. (1998). Ecological Land Classification for Southern Ontario. First Approximation and its Application. SCSS Field guide FG-02. Min. Nat. Resources. Toronto: Queen's Printer for Ontario, 225.

Lockman, I. B., and Kearns, H. S. J. (2016). Forest Root Diseases Across the United States. Available online at: https://www.treesearch.fs.fed.us/pubs/50767 (accessed July 17, 2020).

Ma, D., Yang, G., Mu, L., and Li, C. (2011). Tolerance of ectomycorrhizal fungus mycelium to low temperature and freezing-thawing. Can. J. Microbiol. 57, 328-333. doi: 10.1139/w11-001

McLaughlin, J. A. (2001). Impact of Armillaria root disease on succession in red pine plantations in Southern Ontario. Forest. Chron. 77, 519-524. doi: $10.5558 /$ tfc $77519-3$

McLaughlin, J. A., Hsiang, T., Hayden, G. H., and Greifenhagen, S. (2011). Abiotic and biotic factors used to assess decline risk in red pine (Pinus resinosa Ait.) plantations. Forest. Chron. 87, 99-115. doi: 10.5558/tfc87099-1

Myren, D. T., Laflamme, G., Singh, P., Magasi, L. P., and Lachance, D. (1994). Tree Diseases of Eastern Canada. Available online at: https://nofc.cfs.nrcan.gc. ca/publications?id=10137 (accessed July 20, 2020).

Pearce, M. H., and Malajczuk, N. (1990). Factors affecting growth of Armillaria luteobubalina rhizomorphs in soil. Mycol. Res. 94, 38-48. doi: 10.1016/S0953-7562(09)81262-8

Pietikäinen, J., Pettersson, M., and Bååth, E. (2005). Comparison of temperature effects on soil respiration and bacterial and fungal growth rates. FEMS Microbiol. Ecol. 52, 49-58. doi: 10.1016/j.femsec.2004. 10.002

Raabe, R. (1962). Host list of the root rot fungus, Armillaria mellea. Hilgardia 33, 25-88. doi: 10.3733/hilg.v33n02p025

Redfern, D. B. (1973). Growth and behaviour of Armillaria mellea rhizomorphs in soil. Trans. Br. Mycol. Soc. 61, 569-581. doi: 10.1016/S0007-1536(73)80126-3

Redfern, D. B., and Filip, G. M. (1991). "Inoculum and infection," in Agriculture Handbook. 691, eds C. G. Shaw III, and G. A. Kile (Washington, DC: USDA Forest Service), 48-61.
Rishbeth, J. (1968). The growth rate of Armillaria mellea. Trans. Br. Mycol. Soc. 51, 575-586. doi: 10.1016/S0007-1536(68)80027-0

Rishbeth, J. (1978). Effects of soil temperature and atmosphere on growth of Armillaria rhizomorphs. Trans. Br. Mycol. Soc. 70, 213-220. doi: 10.1016/S0007-1536(78)80033-3

Robinson, C. H. (2001). Cold adaptation in Arctic and Antarctic fungi. New Phytol. 151, 341-353. doi: 10.1046/j.1469-8137.2001.00177.x

Shaw, III, Omdall, D. W., Ramsey-Kroll, A., and Roth, L. F. (2012). lph, L. (2000). Inoculum reduction measures to manage Armillaria root disease in a severely infected stand of Ponderosa pine in South-Central Washington: 35-year results. West. J. Appl. Forest. 15, 92-100. doi: 10.1093/wjaf/15.2.92

Stevens, R. (2019). Efficacy of various Hypholoma spp. and Phlebiopsis gigantea as biocontrol agents against root rotting fungi Armillaria ostoyae (dissertation/master's thesis). Lakehead University, Orillia, ON, Canada.

Thompson, W., and Boddy, L. (1983). Decomposition of suppressed oak trees in even-aged plantations. New Phytol. 93, 277-291. doi: 10.1111/j.1469-8137.1983.tb03431.x

Toussoun, T. A., Bega, R. V., and Nelson, P. E. (eds.). (1970). Root Diseases and Soil-Borne Pathogens. Berkeley, CA: University of California Press.

Voríšková, J., Brabcová, V., Cajthaml, T., and Baldrian, P. (2014). Seasonal dynamics of fungal communities in a temperate oak forest soil. New Phytol. 201, 269-278. doi: 10.1111/nph.12481

Wells, J. M., and Boddy, L. (1995). Effect of temperature on wood decay and translocation of soil-derived phosphorus in mycelial cord systems. New Phytol. 129, 289-297. doi: 10.1111/j.1469-8137.1995.tb04299.x

Yin, X., and Arp, P. A. (1993). Predicting forest soil temperatures from monthly air temperature and precipitation records. Can. J. Forest Res. 23, 2521-2536. doi: $10.1139 /$ x93-313

Conflict of Interest: The authors declare that the research was conducted in the absence of any commercial or financial relationships that could be construed as a potential conflict of interest.

Copyright (c) 2020 Stevens, Reyes and Kanavillil. This is an open-access article distributed under the terms of the Creative Commons Attribution License (CC BY). The use, distribution or reproduction in other forums is permitted, provided the original author(s) and the copyright owner(s) are credited and that the original publication in this journal is cited, in accordance with accepted academic practice. No use, distribution or reproduction is permitted which does not comply with these terms. 